\title{
Fossil plant remains from Oligocene (?) of Farafra Oasis, Egypt
}

\author{
Mona H. Darwish
}

Botany Department, Faculty of Girls

Ain Shams University,Cairo- Egypt.

E-mail: monahd@mailexcite.com.

\author{
Amin Strougo \\ Geology Department, Faculty of Science \\ Ain Shams University, Cairo, Egypt.
}

and

\author{
Wagieh EI Saadawi \\ Botany Department, Faculty of Science \\ Ain Shams University,Cairo,-Egypt. \\ E-mail: elsaadawy@link.com.eg
}

Darwish M.H., Strougo A. \& El-Saadawi W. 2000. Fossil plant remains from Oligocene (?) of Farafra Oasis, Egypt. Taeckholmia 20(2):147-157

Well preserved fragments of fossil leaves of Dipterocarpophyllum, Cyperaceae, Gramineae and a pod-like fruit are described from Oligocene (?) of Farafra Oasis, Egypt

Key words: Cyperaceae, Dipterocarpophyllum, Egypt, Farafra, Fossil-fruits-leaves, Gramineae, Oligocene.

\section{Introduction}

Fossil plant remains have been known from the stratigraphic succession exposed in the Farafra Oasis, since Kräusel (1939); who reported petrified wood logs of Celastrinoxylon celastroides (Schenk.)Kr., and ? Ficoxylon sp. and a fruit cast of Diospyros schweinfurthi Heer, from the Upper Cretaceous of the Farafra Oasis. Chandler (1954) described Paleowetherellia schweinfurthi Heer, a fossil fruit from the Early Tertiary (Paleocene) sediments of Farafra. Gregor \&Hagn (1982) identified several fruits from the middle Danian (Bir Abu Munqar Horizon of Barthel \& Herrmann-Degen, 1981) of Bir Abu Munqar above the Farafra-Dakhla road, viz. aff. Coryphoicarpus globoides Koch, Nipa burtini (Brongniart) Ettinghausen, Cupulopsis klitzschii Gregor , Eyrthropalum sp.(nova sp.?), Stizocaryopsis bartheli Gregor, and Munqaria kraeuseli Gregor.

Most of these records are confined to the interval straddling the Cretaceous Tertiary boundary, and no paleobotanical remains have been described so far from sediments younger than the Paleocene or the basal Eocene of Farafra. 
The present contribution fills partially this gap in our knowledge, since well preserved fragments of various fossil leaves and a pod-like fruit have been collected from a carbonate-sandstone package crowing a group of hillocks situated to the north of Qasr Farafra, whose post-Eocene, possibly Oligocene age, has been recently suggested by Strougo (1996).

\section{Stratigraphic setting and possible age of the plant-bearing horizon}

The stratigraphic succession exposed in Farafra covers mostly the uppermost Cretaceous to Lower Eocene time span. This includes the following formations, in ascending order : Khoman Chalk, Dakhla Shale, Tarawan Chalk, Esna Shale, and Farafra Limestone. In the northern confines of the oasis, Youssef and Abdel-Aziz (1971) discovered a younger unit, mostly composed of fine clastic sediments, containing a mixed Cretaceous and Paleocene planktic foraminiferal assemblage. They called this unit the Ain El Wadi Formation, and ascribed its deposits to the effects of dissolution, precipitation and reworking of older sediments exposed in the vicinity, and their accumulation in depressions during the Pleistocene.

The plant remains discussed in the present work came from a group of three hillocks, known collectively as the Northern Gunna (or Gunnet El Bahariya), lying some $15 \mathrm{~km}$ to the north of Qasr Farafra (Fig. 1). The stratigraphic succession that composes these hillocks consists of a thick package of white chalk at the base "the Khoman Chalk", overlain by several meters of Dakhla Shale and Tarawan Chalk. Near the top, is a thick pile of green shales, the Esna Shale. Crowning the whole comes an interval, several meters thick, made up of tough, excessively hard, grey limestones and sandstones (Fig. 2 a); which contain the plant remains (Fig. 2 b; Fig. 3 a) discussed herein, and are associated with common stromatolitic limestones (Fig. 3 b).

The plant-bearing, stromatolitic limestones of Northern Gunna have been erroneously equated to the Farafra Limestone capping the Esna Shale in the plateau of ElGuss Abu Said to the west and southwest of these hillocks (Youssef and Abdel- Aziz, 1971; Abdel-Kireem and Samir, 1995); probably on the basis of their stratigraphic position. However, it has been shown that the Esna Shale of Northern Gunna correlates only with the lower part of the Esna Shale of El-Guss Abu Said and hence, the greater part of these shales (and the overlying Farafra Limestone) must have been stripped away by erosion from the hillocks of Northern Gunna prior to the formation of the stromatolitic limestones (Strougo, 1996). The latter, very likely appears to be a fresh water deposit and may be correlated with the sandstones and limestones described by Barthel and HerrmannDegen (1981) from south-southeast Abu Mungar and questionably placed by these authors in the Lower Oligocene (Strougo, 1996).

\section{Materials and Methods}

Five blocks were collected by the second author (A.S.) and the Late Prof. Dr. F. Hamza from the stromalitic limestones of Northern Gunna (Fig .1). The blocks include plant remains and vary in colour between grey, whitish and pale yellow. The colour of the fossil plants is slightly different from that of the rock matrix. Plant remains are preserved mainly as impressions without any organic or carbonaceous matter left. Thin ground sections were 
prepared from specimens, which appear to be petrified; being well demarked and distinct from the rock matrix. These sections showed the outlines and the almost uniform thickness of the fine crystalline sedimentation layer cemented to the plant organs but no cellular structure could be detected. In addition these sections showed concentric rings of axial structures. Peel sections (cf. Lacey 1963) were unsuccessful.

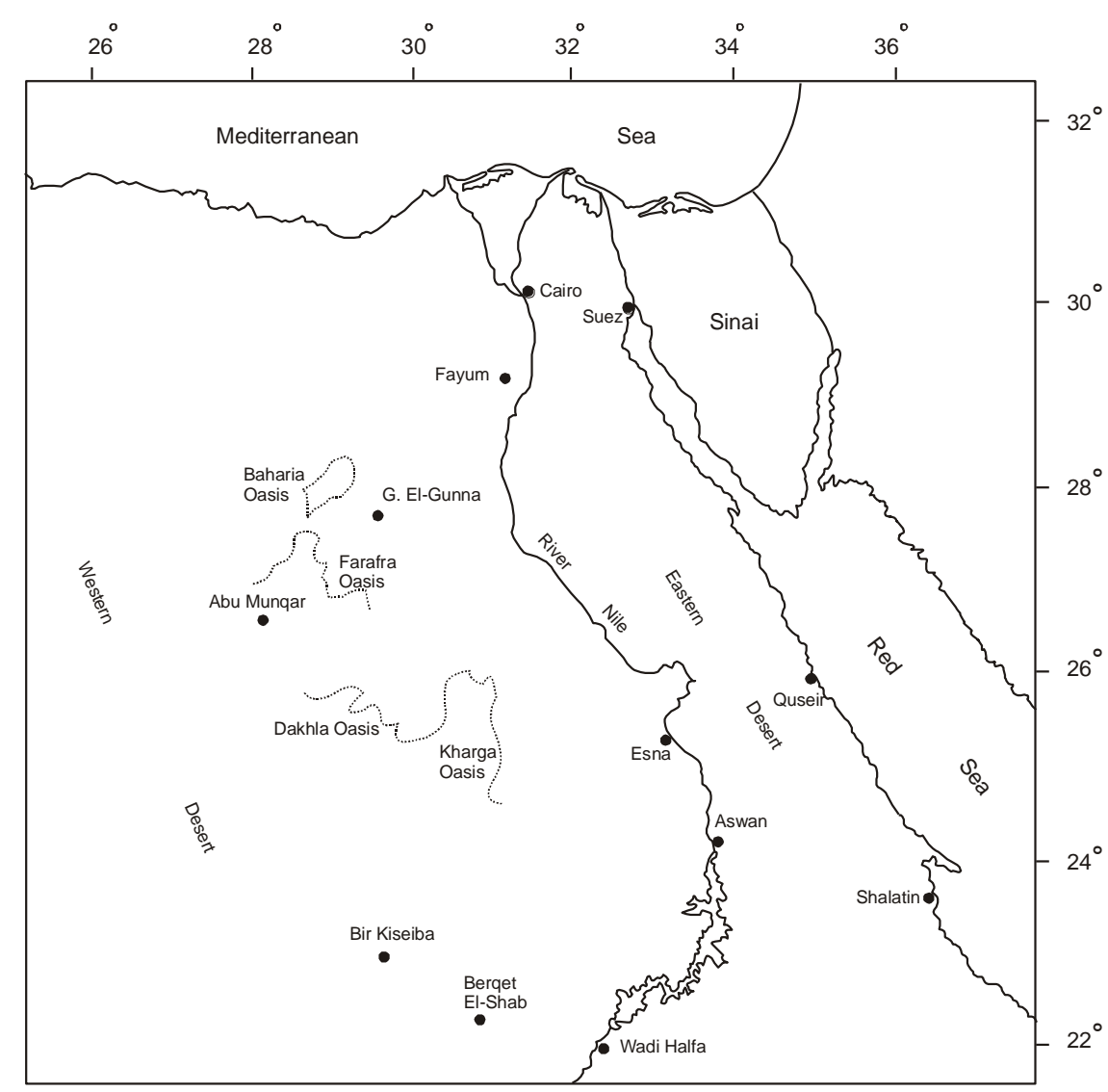

Fig. 1. Location map for the sites reported in the text.

\section{Plant remains}

The blocks are rich with impressions of plant leaves in a fragmentary condition, so that it is difficult, in the present situation, to give full descriptions or precise identifications. There are four types of leaves; two of dicotyledons and two of monocotyledons.

One of the two dicotyledonous leaves (Fig. 4, a-c) is met with several times in the blocks and there are enough features to assign it to the genus Dipterocarpophyllum. A small fragment, showing clear net venation represents the second dicotyledonous leaf but there is no sufficient evidence to permit identification. Thin ground sections showed that 
the axial structures, seen in some of the blocks, consist internally of concentric rings with a hollow center. The nature of these structures, which are about $2 \mathrm{~cm}$ in diameter remains obscure and requires further collection and investigation, however, at this stage it can be said that they are comparable to stromatolites.
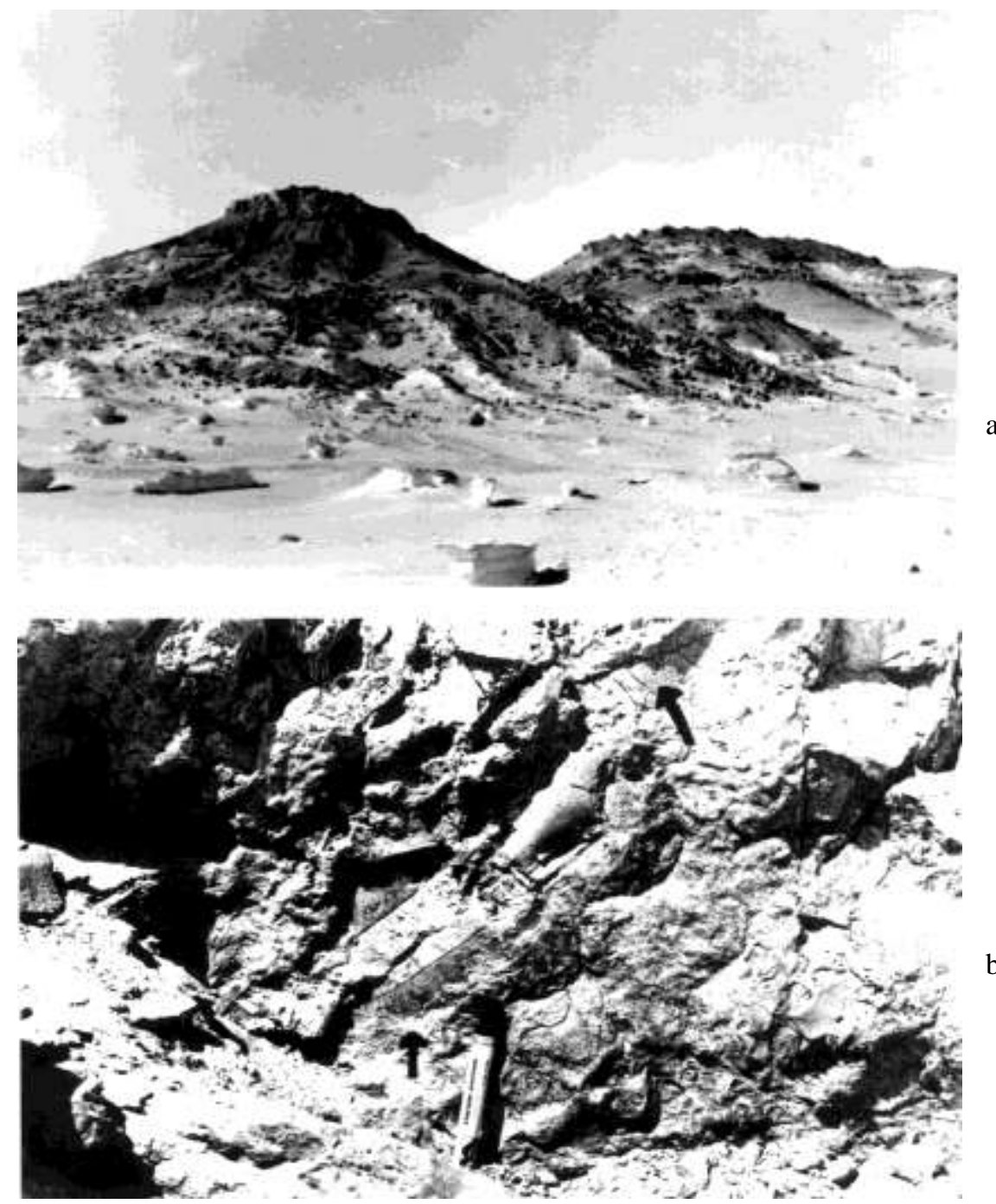

Fig. 2: a. View of Gunnet El Bahariya (note the hard limestones \& sandstones which crown the two hillocks). b. Prints of a number of dicot leaves (arrows) at the site of collection. 

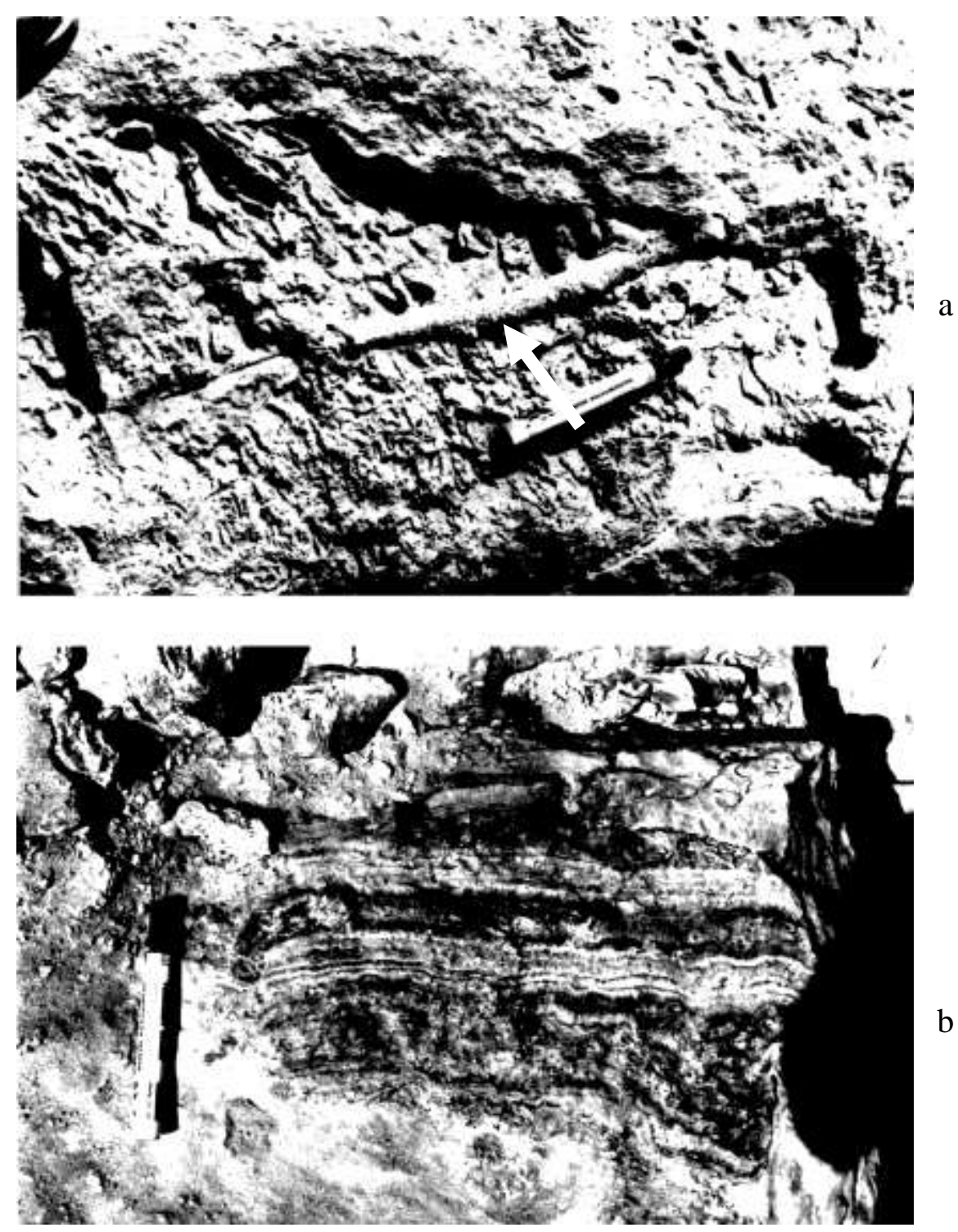

Fig. 3: a. Roots (?) of plants (arrow); no part of which could be chopped off due to the excessive hardness of the stones at this site compared to our light tools. b. Stromatolitic limestones of Gunnet El-Bahariya. 


\section{Description:}

\section{a. Dipterocarpophyllum sp. (Fig. 4, a-c)}

The leaf was large; being at least $10 \mathrm{~cm}$ wide; with the lamina together with a cemented sedimentation layer on lower surface are $6 \mathrm{~mm}$ thick. The lamina has an entire margin and a distinct midrib represented by a deep groove. The lateral veins are given off at an angle of about $62^{\circ}$ and are $0.8-2.5 \mathrm{~cm}$ apart. Their attachment to the midrib varies from opposite to subopposite. One of the main lateral veins shows the pattern of its branching to tertiary veins (Fig. 4, b). There is a layer about $6 \mathrm{~mm}$ thick, lying under lamina and appears to be contiguous with it. This layer does not represent the body of the lamina itself; and is probably a crystalline layer connected to the lamina, a well-known phenomenon in fossilization.

\section{b. Sedge (Cyperaceae) leaf (Fig. 5, a)}

Figure $(5$, a) shows three diverging leaf blades, each is $10-11 \mathrm{~mm}$ wide with a faint or unclear midrib and slightly unequal lamina halves; a character also seen in recent sedge leaves. There are some 16 longitudinally parallel lateral veins. The largest blade fragment is $10 \mathrm{~cm}$ long with almost two parallel margins, which means that the leaf was much longer.

\section{c. Grass (Gramineae) leaf (Fig. 5, b)}

Figure $(5, \mathrm{~b})$ shows fragments of three leaf blades close together and parallel to one another as if preserved in position of growth or preserved while these three leaves were still attached to their stem. The middle blade is about $26 \mathrm{~mm}$. wide at its lower end and 24 $\mathrm{mm}$. wide at its upper end. There is a clear midrib and about 36 longitudinally - parallel veins. Here also, there is a regular layer of fine crystalline sediments, $1-1.5 \mathrm{~mm}$ thick, running underneath the lamina and cemented to it. This fossil leaf is similar to those of the extant genera: Phragmites or Arundo.

\section{d. Pod-like fruit (Fig. 5, c)}

The specimen fragment is $5 \mathrm{~cm}$ long and $1 \mathrm{~cm}$ broad. Seeds appear cleary at the bottom of the specimen. The width of the seed ranges between $2-3 \mathrm{~mm}$ and is about $2 \mathrm{~mm}$. long. The pod contains two rows of seeds, with five clear positions of seeds while scars of other seeds are very faint. 
a

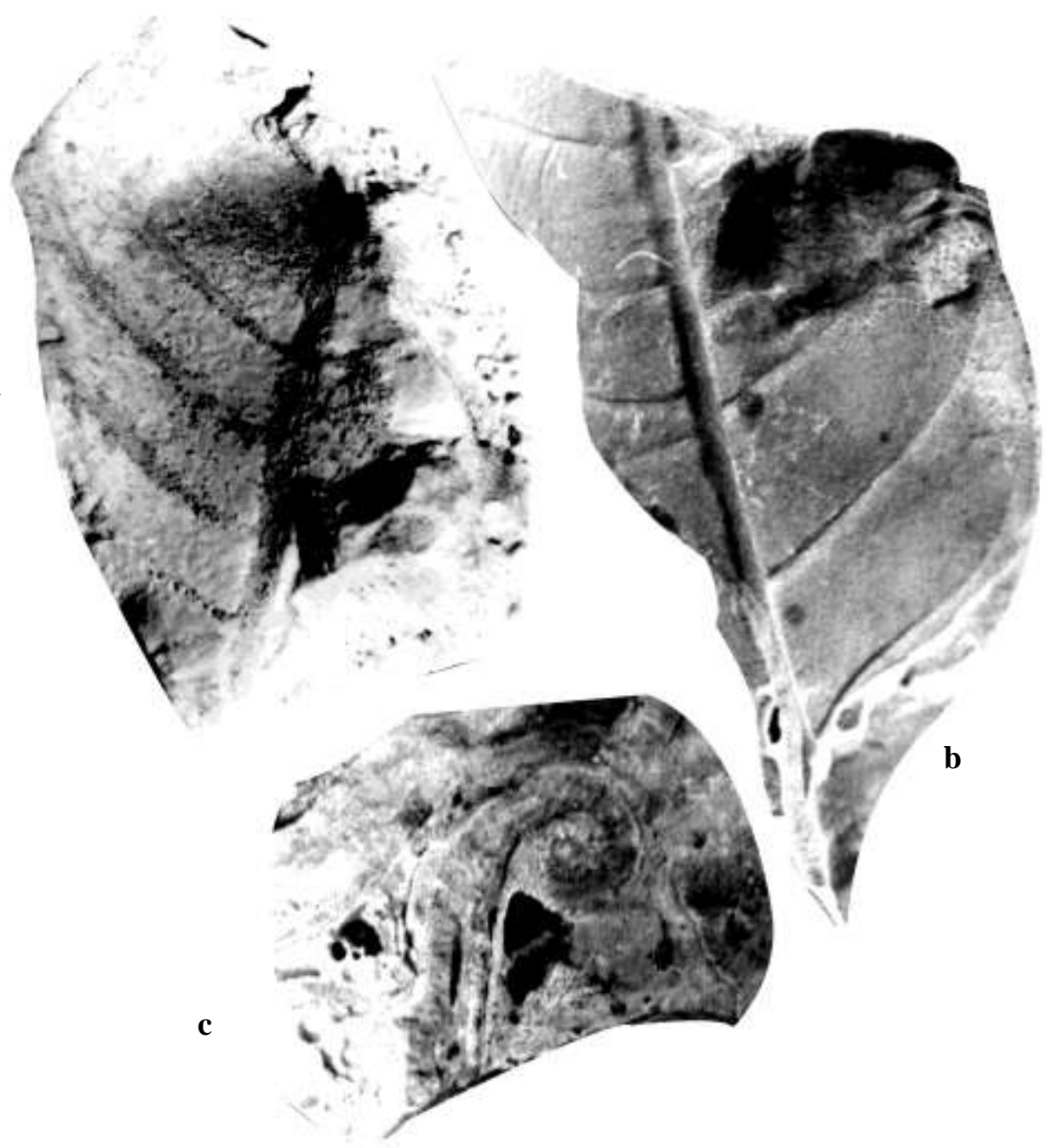

Fig. 4: a. Dipterocarpophyllum sp. Impression of a leaf fragment. x 3/4. b. Dipterocarpophyllum sp. Leaf impression showing tertiary veins at the upper left corner of the fragment. $\mathrm{x}$ ca 1 . c. Dipterocarpophyllum sp. Leaf fragment in cross section showing thickness of crystalline sedimentation layer under lamina. $x$ ca 1. 


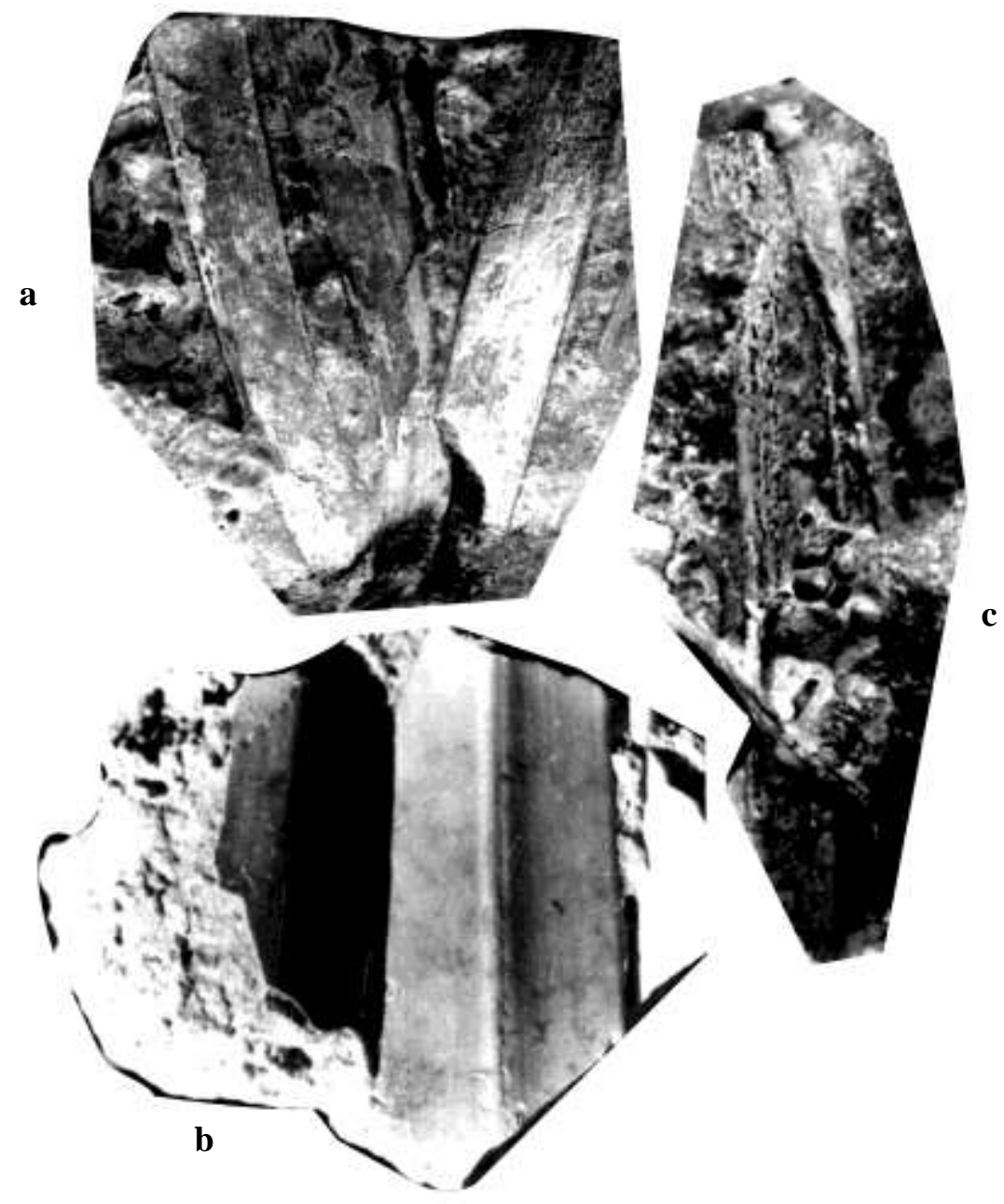

Fig. 5. a. Three diverging cyperaceous leaf fragments with clear parallel veins. x ca 0.9. b. Impressions of graminaceous leaves. $\mathrm{x}$ ca 1

c. Impressions of a pod-like fruit with clear positions of seeds. $x$ ca 1.5. 
Fossil plant remains from Oligocene (?) of Farafra Oasis, Egypt

\section{Discussion}

Fossil remains of Dipterocarpophyllum are reported earlier from Egypt. Dipterocarpophyllum humei and Dipterocarpophyllum zeraibense were described by Seward (1935) from the Cretaceous Nubian Sandstone of Wadi Zeraib, a short distance south of Quseir, near the coast of the Red Sea (Fig. 1). Dipterocarpophyllum kisheibiense from the basal part of the Kiseiba Formation (deposited close to the end of Cretaceous time), northeast of Wadi Halfa and Dipterocarpophyllum abiyadense from Gebel Abiyad (Northern Sudan) (Early Cretaceous age) were described by Lejal-Nicol (1987) as two new species. The present fossil from Farafra Oasis is similar to but not identical with these four leaf species.

Remains of Dipterocarpaceae from ages similar to or younger than those assigned to deposits containing Dipterocarpophyllum species in Egypt are known from other parts of the world. Kräusel (1929), found Dipterocarpophyllum sumatrense from Pliocene? of South Sumarta while Edwards (1923), reported Dipterocarpophyllum gregoryi from Tertiary of Tichara village, southeast Burma. Moreover species of the fossil wood genus Dipterocarpoxylon are known from the Mid-to Upper-Tertiary strata of Southeast Asia and India (cf. Chowdhury, 1969) and from the Miocene of East Africa (cf. Chowdhury, 1969; Schweitzer, 1958). Kräusel (1922), Kräusel \&Stromers ( 1924) and Edwards (1931) applied this generic name in a wider sense incorporating all fossil woods referable to the family Dipterocarpaceae irrespective of their affinities with other genera of the family. The Dipterocarpaceae (Mabberley, 1981; Willis, 1960) contains, at present, 16 genera and 530 species of Palaeotropical, usually tall and little branched trees.

The Cyperaceous leaf described here is not complete to permit sound comparisons. The grass leaf described here is similar to the leaf impression described by Barthoux and Fritel (1925) from Cretaceous beds near Aswan (Fig. 1) and to the leaf of Typhaceae (Sparganium ?) described from the Late Cretaceous of Berqet el. Shab (Fig. 1) by Klitzsch and Lejal-Nicol (1984). The Gramineae genera as Phragmites and Arundo were described by Barthoux and Fritel (1925) from Cretaceous beds near Aswan and by El-Saadawi et al. (1975) from Quaternary (Pleistocene) beds in El-Fayum. For sound conclusions we have to look, however, for more complete material.

The present pod-like fossil fruit is different from all those referred to in the introduction as being reported from the Farafra area or near to it .

\section{Concluding Remarks}

The few fossil plants described here are exclusively angiospermous and all indicate a humid climate. Species of Dipterocarpaceae constitute forest trees of the humid tropics or subtropics, and the species of Cyperaceae are known to be chiefly marsh-plants. Phragmites, Arundo and similar plants also grow in swamps or at swamp margins. The locality, therefore, might have been occupied by large dipterocarpaceous trees under which grew the smaller herbs and grasses of the Cyperaceae and Gramineae, while stromatolites covered mainly mud flats.

The above described fossils and their probable habitat rather confirm the suggestions made by Strougo (1996) that these plant-bearing limestones appear to be Oligocene? fresh water deposits that may be correlated with the questionable Lower 
Oligocene deposits described by Barthel and Herrmann-Degen (1981) from near Abu Mungar.

\section{References}

Abdel-Kireem M.R. \& Samir A.M. 1995. Biostratigraphic implications of the Maastrichian-lower Eocene sequence at the North Gunna section, Farafra Oasis,Western Desert, Egypt . Marine Micropaleont., 26:329-340.

Barthel K.W. \& Herrmann-Degen W. 1981. Late Cretaceous and Early Tertiary Stratigraphy in the Great Sand Sea and its SE margins (Farafra and Dakhla Oases), SW Desert, Egypt. Mitt. Bayer. Staatssam. Palaeont. Hist. Geol., 21: 141- 182.

Barthoux J. C. \& Fritel P. H. 1925. Flore Crétacée du gres de Nubie. Mém. Inst. Egypt. 7:65-119.

Chandler M.E.J. 1954. Some Upper Cretaceous and Eocene fruits from Egypt. Bull. Brit. Mus. (N. H.) Geol. Lond. 2: 149- 187 .

Chowdhury K.A. 1969. Recent Advances in the Anatomy of Tropical Seed Plants.Hindustan Pub. Corr.India.

Edwards W.N. 1923. On some Tertiary plants from South-East Burma . Geol.Mag., London. 60:159-165 .

1931. Fossilium catalogus, Dicotyledones (Ligna). in W. Jongmans (ed), Berlin. 17:1-96.

El-Saadawi W.E., Badawi A.A. \& El-Awamri A.A. 1975. On silicified rhizome fragments of Phragmites communis Trin from the Pleistocene of El- Fayum, Egypt. Palaeontographica Abt. B. 154: 172- 178.

Gregor H.J. \& Hagn H. 1982. Fossil fructifications from the Cretaceous-Paleocene boundary of SW Egypt (Danian, Bir Abu Munqar). Tert.Res. 4: 121-147.

Klitzsch E. \& Lejal- Nicol A. 1984. Flora and Fauna from strata in Southern Egypt and Northern Sudan (Nubia and surrounding areas). Berliner Geowiss. Abh. (A). 50: 47-79.

Kräusel R. 1922. Fossile Hölzer aus dem Tertiär von Süd- Sumatra . Geol. Mijn. Genoot. Nederland . en kolonien Verh . 5: 231- 281.

--- 1929. Fossilen Pflanzen aus dem Tertiär von Süd - Sumatra. Geol. Mijn . Genoot. Nederland . en kolonien Verh. Geol. Ser. 9:1-44.

1939. Ergebnisse der Forschungsreisen Prof. E. Stromers in den Wüsten Ägyptens. III. Die fossilen Floren Ägyptens. Abh. Bay. Akad. Wiss. Math. Nat.Abt. München. 47:1-140 .

\& Stromers E. 1924. Ergebnisse der Forshungsreisen Prof . E. Stromers in den Wüsten Ägyptens. Abh. Bayer. Akad. Wiss . München. 30 :1- 48.

Lacey W.S. 1963. (in J.D.Carthy and c.L. Duddington editors) Palaeobotanical Techniques: View points in Biology. 2: 202-243 .

Lejal- Nicol A. 1987. Flores nouvelles du Paléozoique et du Mésozoique de L'Égypte et du Soudan Septentrional. Berliner Geowiss. Abh. 75(A):151-248.

Mabberley D.J. 1981. The Plant-book, A portable dictionary of the higher plants. Cambridge University Press. 
Schweitzer H. J. 1958. Die fossilen Dipterocarpaceen-Hölzer. Palaeontographica, 105B: $1-66$.

Seward A.C. 1935. Leaves of dicotyledons from the Nubian Sandstone of Egypt. Geological Survey of Egypt, Cairo 1- 20.

Strougo A. 1996. The lower Libyan stratigraphic succession in Farafra and Nile Valley: A new correlation . M.E.R.C. Ain Shams Univ., Earth Sci. Ser.10:53-74.

Willis J.C. 1960. A dictionary of the Flowering plants and Ferns. Cambridge University Press.

Youssef M.I. \& Abdel -Aziz W. 1971. Biostratigraphy of the Upper Cretaceous-Lower Tertiary in Farafra Oasis, Libyan Desert Egypt. Symp. Geol. Libya, Tripoli, 1979; Fac. Sci. Univ. Libya: 227-249. 